\title{
Early appearance of key transcription factors influence the spatiotemporal development of the human inner ear
}

\section{Lejo Johnson Chacko ${ }^{1}$. Consolato Sergi ${ }^{2}$. Theresa Eberharter ${ }^{1} \cdot$ Jozsef Dudas $^{1} \cdot$ Helge Rask-Andersen ${ }^{3}$. Romed Hoermann ${ }^{4} \cdot$ Helga Fritsch ${ }^{4} \cdot$ Natalie Fischer $^{5} \cdot$ Rudolf Glueckert $^{1,5} \cdot$ Anneliese Schrott-Fischer $^{1}$ (D)}

Received: 15 April 2019 / Accepted: 22 September 2019 / Published online: 2 December 2019

(C) The Author(s) 2020

\begin{abstract}
Expression patterns of transcription factors leucine-rich repeat-containing $G$ protein-coupled receptor 5 (LGR5), transforming growth factor- $\beta$-activated kinase-1 (TAK1), SRY (sex-determining region Y)-box 2 (SOX2), and GATA binding protein 3 (GATA3) in the developing human fetal inner ear were studied between the gestation weeks 9 and 12. Further development of cochlear apex between gestational weeks 11 and 16 (GW11 and GW16) was examined using transmission electron microscopy. LGR5 was evident in the apical poles of the sensory epithelium of the cochlear duct and the vestibular end organs at GW11. Immunostaining was limited to hair cells of the organ of Corti by GW12. TAK1 was immune positive in inner hair cells of the organ of Corti by GW12 and colocalized with p75 neurotrophic receptor expression. Expression for SOX2 was confined primarily to the supporting cells of utricle at the earliest stage examined at GW9. Intense expression for GATA3 was presented in the cochlear sensory epithelium and spiral ganglia at GW9. Expression of GATA3 was present along the midline of both the utricle and saccule in the zone corresponding to the striolar reversal zone where the hair cell phenotype switches from type I to type II. The spatiotemporal gradient of the development of the organ of Corti was also evident with the apex of the cochlea forming by GW16. It seems that highly specific staining patterns of several transcriptions factors are critical in guiding the genesis of the inner ear over development. Our findings suggest that the spatiotemporal gradient in cochlear development extends at least until gestational week 16.
\end{abstract}

Keywords Inner ear · Human · Transcription factors · Immunohistochemistry · SOX2 · TAK1 · GATA3 · Electron microscopy

Anneliese Schrott-Fischer

Annelies.Schrott-Fischer@i-med.ac.at

1 Department of Otorhinolaryngology, Medical University of Innsbruck, Anichstrasse 35, 6020 Innsbruck, Austria

2 Department of Laboratory Medicine and Pathology and Department of Pediatrics, University of Alberta, 8440112 St, NW, Edmonton, AB T6G 2B7, Canada

3 Department of Surgical Sciences, Head and Neck Surgery, Section of Otolaryngology, Uppsala University Hospital, SE-751 85 Uppsala, Sweden

4 Department of Anatomy, Histology \& Embryology, Division of Clinical \& Functional Anatomy, Medical University of Innsbruck, Muellerstrasse 59, 6020 Innsbruck, Austria

5 University Clinics Innsbruck, Tirol Kliniken, Anichstrasse 35, 6020 Innsbruck, Austria

$\begin{array}{ll}\text { Abbreviations } \\ \text { DAB } & \text { Diaminobenzidine } \\ \text { GATA3 } & \text { GATA binding protein } 3 \\ \text { GER } & \text { Greater epithelial ridge } \\ \text { GW } & \text { Gestational week } \\ \text { HE } & \text { Hematoxylin/eosin } \\ \text { IHC } & \text { Inner hair cells } \\ \text { KO } & \text { Kölliker's organ } \\ \text { LER } & \text { Lower epithelial ridge } \\ \text { LGR5 } & \text { Leucine-rich repeat-containing G } \\ & \text { protein-coupled receptor 5 } \\ \text { OHC } & \text { Outer hair cells } \\ \text { PAN } & \text { Primary auditory neurons } \\ \text { PBS } & \text { Phosphate-buffered saline } \\ \text { PFA } & \text { Paraformaldehyde } \\ \text { SOX2 } & \text { SRY (sex-determining region Y)-box 2 } \\ \text { SG } & \text { Spiral ganglia } \\ \text { SGC } & \text { Satellite glial cells } \\ \text { TAK1 } & \text { Transforming growth factor- } \beta \text {-activated kinase-1 }\end{array}$




\section{Introduction}

Hearing impairments and balance disorders are major health conditions estimated to affect significant sections of the global population (Agrawal et al. 2009; Bowl and Dawson 2018). Because of the lack of regenerative capacity in the adult human cochlea, preservation of every single hair cell and spiral ganglion cell is vital (Liu et al. 2015; Smeti et al. 2012). Although vestibular hair cells do possess low levels of regenerative capacity, this, however, declines with aging and is not adequate to cope with hair cell loss (Burns and Stone 2017; Rauch et al. 2001). Sustained efforts to understand processes underlying inner ear development using murine models have revealed roles for several quintessential transcription factors like leucine-rich repeat-containing $G$ protein-coupled receptor 5 (LGR5) (Bramhall et al. 2014), transforming growth factor- $\beta$-activated kinase-1 (TAK1) (Parker et al. 2011), SOX2 (Dvorakova et al. 2016), and GATA binding protein 3 (GATA3) (Karis et al. 2001). The expression profiles of these transcriptional factors and their functionality in human inner ear development are not currently clear. Previous research had examined the expression profiles of the transcription factors SOX2, S0X9, and SOX10 in the cochlea anlage (Locher et al. 2013).

Spontaneous hair cell regeneration observed in neonatal murine cochlea suggest continuous availability of Wntresponsive progenitor cells positive for LGR5 (Chai et al. 2012). Cells positive for transcription factor LGR5 serve as hair cell progenitors in neonatal mammalian cochlea following hair cell injury with fresh hair cell regeneration promoted by blockage of Notch signaling (Bramhall et al. 2014). A small-molecule approach using LGR5+ supporting cells was able to generate inner ear organoids, which differentiated into hair cells (McLean et al. 2017). Distinct progenitor populations in neonatal sensory epithelia differentiated into cell types specific to the vestibulum and the cochlea (McLean et al. 2016). The other similar G protein coupled receptor LGR6, a WNT signaling mediator is, however, able to generate more hair cells than LGR5+ progenitors (Zhang et al. 2018). In situ hybridization probes specific for LGR5 have been able to localize LGR5 mRNA in the prosensory domain of the developing human cochlea at gestational week 9 (Roccio et al. 2018).

Other known transcription factors like the TAK1, a mitogen-activated protein kinase, play multiple roles in varied biological processes. In prenatal murine inner ear specimens, its expression although broadly expressed is gradually restricted to specific subpopulations of supporting cells (Parker et al. 2011). TAK1 signaling activation although dependent on the expression of bone morphogenetic protein $7(\mathrm{Bmp} 7)$ regulates determination of frequency specificity of hair cells characteristics along their tonotopic axis (Mann et al. 2014). Its expression profile in the developing human inner ear is currently unknown.

In the developing human inner ear, the prosensory domain constitutes a portion of the developing cochlear epithelium selectively expressing the transcription factors SOX2, SOX9/SOX10 (Locher et al. 2013). SOX2 expression is limited to the prosensory domain of the developing murine inner ear (Kiernan et al. 2005) although supporting cells of the developing organ of Corti express the SOX2 (Mak et al. 2009). Differentiating hair cells were present at gestational week 10 in the fetal prosensory domain (Johnson Chacko et al. 2017) where the high-mobility transcription factor SOX2 downregulates it at gestational week 12 (Locher et al. 2013). This sets the stage for the cessation of the prosensory domain formation. Immediately before this, the cell cycle exit progression of spiral ganglion neurons from base to apex of the cochlear occurs (between gestational weeks 8 and 12) (Fritzsch et al. 2019; Matei et al. 2005; Roccio et al. 2018). Scant information currently exists on the expression profile of the SOX2 transcription factor in the developing human vestibule. Mutations in SOX2 cause sensorineural hearing loss in humans (Hagstrom et al. 2005) while decreased SOX2 expression in murine causes overproduction of inner hair cells. SOX2 has a dynamic role in prosensory domain formation where a mutually antagonistic relationship with Atoh1 exists. This antagonistic relationship prevents overproduction of inner ear hair cells (Dabdoub et al. 2008). Additionally, SOX2 expression enables induction of neuronal fate in non-sensory regions of the cochlea (Puligilla et al. 2010).

Mutations causing haploinsufficiency for the transcription factor GATA3 cause sensorineural hearing loss in humans (Van Esch et al. 2000). GATA3 expression is widespread in all developing neurons but declines in the type I primary auditory neurons (PAN) as they keep maturing before hearing onset (Nishimura et al. 2017). GATA3 expression is widespread throughout the murine auditory sensory epithelium while being limited to the striola reversal zone of the utricle (Alvarado et al. 2009; Karis et al. 2001). During murine inner ear development, GATA3 guides signaling of prosensory genes while directing differentiation of cochlear neurosensory cells (Duncan and Fritzsch 2013). Other studies have evidenced that GATA3 expression is crucial towards the development of the otic vesicle and the semicircular canals (Moriguchi et al. 2018) while activating FGF10 in the early inner ear (Economou et al. 2013; Pauley et al. 2003). In the developing human fetus, the expression of GATA3 presents in the cochlear duct and the spiral ganglion between gestational weeks 8 and 12 (Roccio et al. 2018).

Recent studies have identified fetal human cochlear hair cells exit cell cycle in an apical to the basal direction (using the cell cycle inhibitor p27Kip1) during gestational weeks (GW) 8 to 12 (Roccio et al. 2018). In the developing murine inner ear, the same was previously observed in apex to base in 
hair cells and base to apex cell cycle exit in spiral ganglion neurons by analyzing terminal mitosis using BrdU (Kopecky et al. 2013; Matei et al. 2005). The hair cell differentiation progresses from the cochlear base towards the cochlear apex during the same time point (Johnson Chacko et al. 2017; Locher et al. 2013; Roccio et al. 2018). Hence, several transcription factors are active in the developing murine inner ear. The aim of the present investigation was to identify their expression pattern and functional relevance in connection with the development of auditory and vestibular receptors in the human inner ear. To evaluate inner ear development during the GW9-12, we focused on the immune staining for the selected markers on the sensory epithelia of the cochlea and the vestibular organ.

\section{Materials and methods}

\section{Embryonic fetal specimens}

Eight human fetuses of varying gestational ages (2/GW9, 1/GW10, 2/GW11, 1/GW12, 1/GW14, and 1/GW16) were utilized for this study.

Trained anatomists and embryologists assessed these to ascertain that the specimens used in this study were devoid of any clinical abnormalities or malformations. Quantification of features like crown-rump length, external and internal morphology enabled differentiation of gynecological age.

Specimens aged between GW9 and GW12 used in this study were obtained immediately after legally permitted abortion procedures according to the Austrian law ( $\$ 97 \mathrm{StGB}$ of the Austrian Criminal Law as promulgated on 13th November 1998, Federal Law Gazette I). Cadaver donations to the Division of Clinical and Functional Anatomy of the Medical University of Innsbruck for scientific and educational purposes occur only with the informed consent of the donor collected before death. The donors declare during their lifetime that their dead bodies are to be consigned to the anatomical institute for research purposes and the education and advanced training of medical doctors. All embryological body and tissue donations (between the gestational ages 8 and 12) are also released to the anatomical institute by the legally entitled person (mother) accompanied by written consent. In Austria, research projects using these anatomical tissue samples do not need any further approval by an ethics committee of the University.

The other samples (GW14 and older) are from the filing system of the Institute of Pathology of the Medical University of Innsbruck. For the usage of these specimens, an ethical commission vote was obtained before commencing this research. This study was approved by the Ethical Commission of the Medical University of Innsbruck (Studienzahl UN2817 Sitzungsnummer 249/ 4.5; original title of the research proposal: Immunhistochemische Untersuchung von Felsenbeinen mit dazugehöriger Hörbahn). In Austria, there is no requirement for a consent of the parents or relatives for a clinical autopsy performed in a medical institution $\S 25$ KAKuG Leichenöffnung (Obduktion) (Krankenanstaltenund Kuranstaltengesetz). [(1) The corpses of deceased patients in public hospitals are to be autopsied if the autopsy has been ordered by sanitary or criminal prosecutors, or if it is necessary for public or scientific interests, in the situation of diagnostic uncertainty of the case or after surgical intervention.

(2) If none of the cases mentioned in paragraph 1 is present and the deceased has not consented to an autopsy during his lifetime, an autopsy may only be carried out with the consent of the next of kin.

(3) A copy of the medical history shall be recorded for each autopsy and kept in accordance with $\S 10,1$ Z. 3 .

In the past, $\S 25 \mathrm{KAKuG}$ was labeled as $\S 25 \mathrm{KAG}$ (Krankenanstaltengesetz).]

However, in specific cases, a limited autopsy or a postmortem biopsy of one or two organs with closed body was performed in lieu of a full autopsy. In Austria, this autopsy procedure allows institutions to keep the autopsy rate to a higher level than the level of other Western countries permitting high standards of quality assurance and quality controls in most of the healthcare institutions (Beat et al. 2012; McHanwell et al. 2008).

\section{Tissue preparation for histology and immunohistochemistry on paraffin sections}

Temporal bone specimens were excised immediately following abortions and then fixed via immersion in a solution of 4\% paraformaldehyde (PFA) in phosphate-buffered saline (PBS, $0.1 \mathrm{M}$ ) at a $\mathrm{pH}$ of 7.4 overnight. PBS was used to rinse the specimens following which they were dehydrated and embedded in paraffin utilizing a histological infiltration processor (Miles Scientific Inc., Naperville, IL, USA). Using an HM 355S microtome (Microm, Walldorf, Germany), embedded specimens were then serially sectioned at $4 \mu \mathrm{m}$ thickness and mounted onto Superfrost ${ }^{\mathrm{TM}}$ Plus slides (Menzel, Braunschweig, Germany). The sections were then dried overnight at room temperature, following which the slides were incubated at $60{ }^{\circ} \mathrm{C}$ for $2 \mathrm{~h}$ to enable the sections to adhere firmly to the glass surface. Every tenth section was stained with hematoxylin/eosin (HE) (Shandon Varistain 24-4, Histocom Vienna, Austria). This enabled both orientation and identification of the anatomical landmarks. 
Table 1 Antibodies used for immunohistochemistry

\begin{tabular}{|c|c|c|c|c|c|}
\hline Ab clone & $\begin{array}{l}\text { Localization } \\
\text { pattern }\end{array}$ & $\begin{array}{l}\text { Host } \\
\text { description }\end{array}$ & Background & $\begin{array}{l}\mathrm{Ab} \text { dilution } \\
\text { pre-treatment }\end{array}$ & Supplier cat. no. \\
\hline $\begin{array}{l}\text { Monoclonal anti-nerve } \\
\text { growth factor receptor } \\
\text { (NGFR p75) clone } \\
\text { ME20.4 }\end{array}$ & $\begin{array}{l}\text { Diffuse } \\
\quad \text { cytoplas- } \\
\text { mic }\end{array}$ & $\begin{array}{l}\text { Mouse } \\
\text { mono- } \\
\text { clonal }\end{array}$ & $\begin{array}{l}\text { Dudas et al. } \\
2018\end{array}$ & $\begin{array}{r}1: 200 \mathrm{CC} 1 \\
\text { standard }\end{array}$ & Sigma N 5408 \\
\hline LGR5 & $\begin{array}{l}\text { Diffuse } \\
\quad \text { cytoplas- } \\
\text { mic }\end{array}$ & $\begin{array}{l}\text { Rabbit } \\
\text { poly- } \\
\text { clonal }\end{array}$ & $\begin{array}{c}\text { Kim et al. } \\
2018\end{array}$ & $1: 100$ & $\begin{array}{l}\text { Novus } \\
\text { Biologicals } \\
\text { NB- } \\
\text { P1-28904G }\end{array}$ \\
\hline TAK1 (Thr184) & $\begin{array}{l}\text { Diffuse } \\
\text { cytoplas- } \\
\text { mic }\end{array}$ & $\begin{array}{l}\text { Rabbit } \\
\text { poly- } \\
\text { clonal }\end{array}$ & N/A & $1: 100$ & $\begin{array}{l}\text { Bioss bs-3436R } \\
\quad \text { A555 }\end{array}$ \\
\hline SOX2 & $\begin{array}{l}\text { Diffuse } \\
\text { cytoplas- } \\
\text { mic }\end{array}$ & $\begin{array}{l}\text { Rabbit } \\
\text { mono- } \\
\text { clonal }\end{array}$ & $\begin{array}{l}\text { Okita et al. } \\
2007\end{array}$ & $1: 100$ & $\begin{array}{l}\text { Cell Signaling } \\
\quad \# 3579\end{array}$ \\
\hline GATA3 (L5-823) & $\begin{array}{l}\text { Diffuse } \\
\quad \text { cytoplas- } \\
\text { mic }\end{array}$ & $\begin{array}{l}\text { Mouse } \\
\text { mono- } \\
\text { clonal }\end{array}$ & $\begin{array}{l}\text { Higgins } \\
\text { et al. } \\
2007\end{array}$ & $\begin{array}{l}\text { Ready-to-use } \\
\text { CC1 } \\
\text { standard }\end{array}$ & $\begin{array}{l}\text { Ventana Roche } \\
\text { Mannheim, } \\
\text { Germany } \\
760-4897\end{array}$ \\
\hline Myosin VIIa & $\begin{array}{l}\text { Diffuse } \\
\quad \text { cytoplas- } \\
\text { mic }\end{array}$ & $\begin{array}{l}\text { Rabbit } \\
\text { poly- } \\
\text { clonal }\end{array}$ & $\begin{array}{l}\text { Soni et al. } \\
2005\end{array}$ & $\begin{array}{r}1: 800 \mathrm{CC} 1 \\
\text { standard }\end{array}$ & $\begin{array}{l}\text { Proteus } \\
\text { Biosciences, } \\
\text { CA, USA } \\
\# 25-6790\end{array}$ \\
\hline $\begin{array}{l}\text { IgG2a kappa isotype } \\
\text { control (eBM2a), } \\
\text { Alexa Fluor } 488\end{array}$ & & Mouse & $\begin{array}{l}\text { Lindsay } \\
\text { et al. } \\
2016\end{array}$ & $1: 100$ & $\begin{array}{l}\text { eBioscience }^{\mathrm{TM}} \\
\# 53-4724-80\end{array}$ \\
\hline
\end{tabular}

\section{Antisera}

The hosts, dilutions, and sources of primary antibodies utilized are listed in Table 1.

\section{Immunohistochemistry}

Immunohistochemistry was performed utilizing a Ventana Roche ${ }^{\circledR}$ Discovery XT Immunostainer (Mannheim, Germany), applying a DAB-MAP discovery research standard procedure. When required, antigen retrieval was performed by epitope unmasking via a heat induction methodology performed while the sections were immersed in EDTA buffer (Cell Conditioning Solution CC1, Ventana 950-124).

The sections were incubated with the appropriate primary antibodies at $37{ }^{\circ} \mathrm{C}$ for $1 \mathrm{~h}$ and then with the Discovery Universal Secondary Antibody, Ventana 760-4250, at room temperature for $30 \mathrm{~min}$. Antibody detection was then attained employing the DAB-MAP Detection Kit (Ventana 760-124) utilizing a combinatorial approach involving the diaminobenzidine (DAB) development method with copper enhancement followed by counterstaining with hematoxylin (Ventana 7602021) for $4 \mathrm{~min}$. The stained sections were then dehydrated using an upgraded alcohol series, cleared with xylene, and mounted permanently with Entellan® (Merck, Darmstadt, Germany).
Positive controls (e.g., small intestine, brain, and pancreas) were supplemented to each experiment. Negative controls were acquired by replacing the primary antibodies with reaction buffer or substituting them with isotypematching immunoglobulins. These controls never yielded any immunostaining.

\section{Image analysis of the HE staining and immunohistochemistry}

All sections were imaged using a Zeiss AxioVision 4.1 microscope software coupled to an AxioCam HRc color camera and an AxioPlan2 microscope (Zeiss, Jena, Germany). The immune-stained sections were analyzed at $\times 20$ magnification utilizing a TissueFaxs Plus System coupled onto a Zeiss® Axio Imager Z2 Microscope (Jena, Germany). Analyzed sections were then acquired using the TissueFaxs (TissueGnostics®, Vienna, Austria).

\section{Fluorescence immunohistochemistry}

Fluorescence immunohistochemistry was performed utilizing a Ventana Roche ${ }^{\circledR}$ Discovery XT Immunostainer (Mannheim, Germany). The sections were incubated with the primary and secondary antibodies for $1 \mathrm{~h}$. The secondary antibodies used were the donkey anti-rabbit Alexa Fluor® 488 (ThermoFischer Scientific \#A-21206), 
donkey anti-rabbit Alexa Fluor ${ }^{\circledR} 594$ (ThermoFischer Scientific \#R37119), and donkey anti-mouse Alexa Fluor® 488 (ThermoFischer Scientific \#R37114).

\section{Image analysis of fluorescence IHC sections}

The immune-stained sections were digitized at $\times 40$ and $\times 63$ magnifications using a TissueFAXS Plus System coupled onto a Zeiss ${ }^{\circledR}$ Axio Imager Z2 microscope (Jena, Germany). Image acquisition was performed using the TissueFAXS software (TissueGnostics ${ }^{\circledR}$, Vienna, Austria).

\section{Tissue preparation for transmission electron microscopy analysis}

Four fetal inner ear specimens (1/GW/09, 1/GW11, 1/GW14, and $1 / \mathrm{GW} 16)$ were detached and divided mid-modularly and were fixed in $2.5 \%$ glutaraldehyde and $2 \%$ paraformaldehyde buffered in sodium cacodylate $(0.1 \mathrm{M}, \mathrm{pH}=7.4)$ overnight at $4{ }^{\circ} \mathrm{C}$. Since the development of the principal fluid spaces in the fetal inner ear was not yet complete, this partitioning of the cochleae allowed for excellent fixation quality for ultrastructure analysis. Subsequently, it was rinsed in sodium cacodylate buffer and post-fixed in $1 \%$ osmium tetroxide in distilled water for $3-4 \mathrm{~h}$ at $4{ }^{\circ} \mathrm{C}$. Again, samples were rinsed again then dehydrated in graded ethanol series and embedded in EPON resin.

Ultrathin sections $(90 \mathrm{~nm})$ were cut on a Reichert Ultracut S microtome (Leica Microsystem, Wetzlar, Germany) with an ultra-diamond knife, mounted on dioxan-formvar-coated slot grids (\#G2500C, Christine Gröpl, Elektronenmikroskopie, Tulln, Austria), and stained $35 \mathrm{~min}$ with $0.5 \%$ (w/v) uranyl acetate, $\mathrm{pH} 4.4$, and $10 \mathrm{~min}$ with $3 \%(\mathrm{w} / \mathrm{v}$ ) lead citrate, $\mathrm{pH} 12$ (Leica Ultrostainer, Leica Microsystem, Wetzlar, Germany). The ultrathin sections were examined with a Philips CM 120 transmission electron microscope at $80 \mathrm{kV}$ (FEI, Eindhoven, Netherlands) equipped with a MORADA digital camera (Olympus SIS, Münster, Germany).

\section{Results}

Expression of the adult stem cell marker LGR5 was apparent in the fetal cochlea from the gestational week (GW) 11 and onwards (Fig. 1a-c). The immunostaining was restricted to the apical poles of the cells of the cochlear duct as well as to the satellite glial cells (SGC) of spiral ganglia (SG) at this stage. LGR5 expression was also apparent in the apical poles of the vestibular hair cells of the fetal cristae ampullaris (Fig. $1 \mathrm{~d}-\mathrm{f}$ ). The erythrocytes projecting towards the cristae ampullaris were immune positive for the hematopoietic stem cell marker, LGR5, and served as an internal control (Fig. 1df). Parallel expression profiles for this marker were also apparent in the human fetal utricle (Fig. 1g-i) with the apical poles immune stained. Towards GW12, the expression for the LGR5 is limited to the inner hair cells of the maturing organ of Corti (Fig. 1j-1). The immune staining for this antibody is apparent in the apical and basal poles of the inner hair cells (IHCs) at this stage of development.

The expression of the kinase moiety TAK 1 first presents at GW12 in the IHC of the developing hearing organ (Fig. 2f). Immune staining for this transcription factor is absent in the surrounding supporting cells of the fetal cochlea during this stage of development. The expression for the neurotrophin receptor, p75NTR, is apparent at all the stages (GW9-12). As previously reported (Johnson Chacko et al. 2017), we examined the expression (Fig. 2c, g, k) of this low-affinity neurotrophin receptor colocalizing with TAK1 (Fig. 2h) in both the IHC and outer hair cells (OHCs) at GW12. Nerve fibers immune positive for $\mathrm{p} 75 \mathrm{NTR}$ project towards the middle turn of the future organ of Corti and penetrate the sensory epithelia. This low-affinity receptor expression was also present in the cells surrounding the spiral ganglions (Fig. 3b, d). Myosin VIIa immune-positive cells are present in the sensory epithelia at GW12 (Fig. 3c, d) with the p75NTR immune staining appearing even in the hair cells at GW12 (Fig. $2 \mathrm{~g}, \mathrm{~h}$ ). The high-mobility transcription factor SOX2 (Fig. $4 \mathrm{c})$, previously described in the cochlear duct epithelium at GW10 (Locher et al. 2013) was expressed in the supporting cells and a few of the hair cells of the maturing utricle.

Immune staining for the transcription factor GATA3 occurred in the cochlear sensory epithelia as well as the maturing spiral ganglia (Fig. 5(a')). Expression for this transcription factor presents in the hair cells of striolar region of both the saccule (Fig. 5(a")) and the utricle (Fig. 5(a"')) at GW11. High expression for the transcription factor myosin VIIa first showed up in the vestibular hair cells at GW9 (Fig. 5(b)) and later in the cochlear hair cells at GW11 (Fig. 5(c)).

\section{Electron microscope images (GW9 to GW16)}

At GW9, the cochlear hair cells are still absent and undifferentiated cells were only observed overall in the cochlear duct (Fig. 6a). At GW11, the future hair cells can be already be recognized (Fig. 6b). Ongoing morphologic differentiation was seen in the future organ of Corti such as dense cytoplasmic aggregations. The first signs of entry of nerve fibers in the sensory epithelia are evident at this stage. The fibers course between future cochlear hair cells. At higher magnification, the nerve fibers penetrate the sensory epithelium beneath developing hair cells (Fig. $6 c$ arrowheads).

There is a basal to the apical gradient in the development of the organ of Corti with differentiation progressing faster along the basal turn of the cochlea. The OHCs and IHCs are quite 
Fig. 1 Immune-stained sections of the developing inner ear during the gestational weeks 11 to 12 . a, $\mathbf{d}, \mathbf{g}, \mathbf{j}$ Cell nuclei stained with DAPI. $\mathbf{b}, \mathbf{c}$ Immune staining for the LGR5 antibody presents at GW11 in the apical pole of the cochlear duct and the satellite glial cells of the spiral ganglia. $\mathbf{e , f}$ Immune staining for LGR5 at the apical pole of the cristae ampullaris. h, i Immune staining for LGR5 at the apical pole of the cristae ampullaris. $\mathbf{k}$, $\mathbf{l}$ Inner hair cells immune positive for the LGR5 marker at GW12. m-o Positive control section of the human intestine with the LGR5 immune staining present in the intestinal epithelial cells. Scale bars: a-c $50 \mu \mathrm{m} ; \mathbf{d}-\mathbf{i} 100 \mu \mathrm{m} ; \mathbf{j}-\mathbf{I}$ $50 \mu \mathrm{m} ; \mathbf{m}-\mathbf{0} 50 \mu \mathrm{m}$
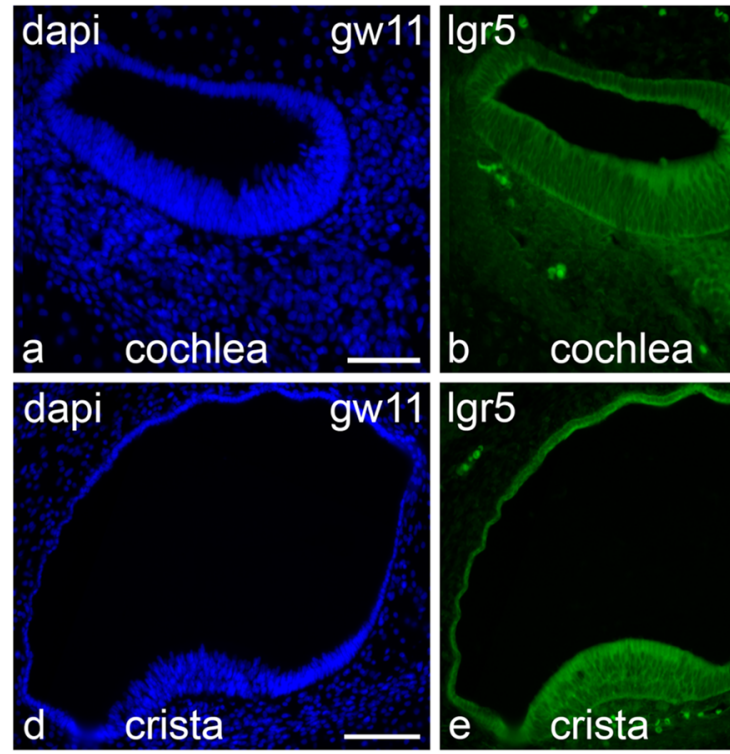

gw11
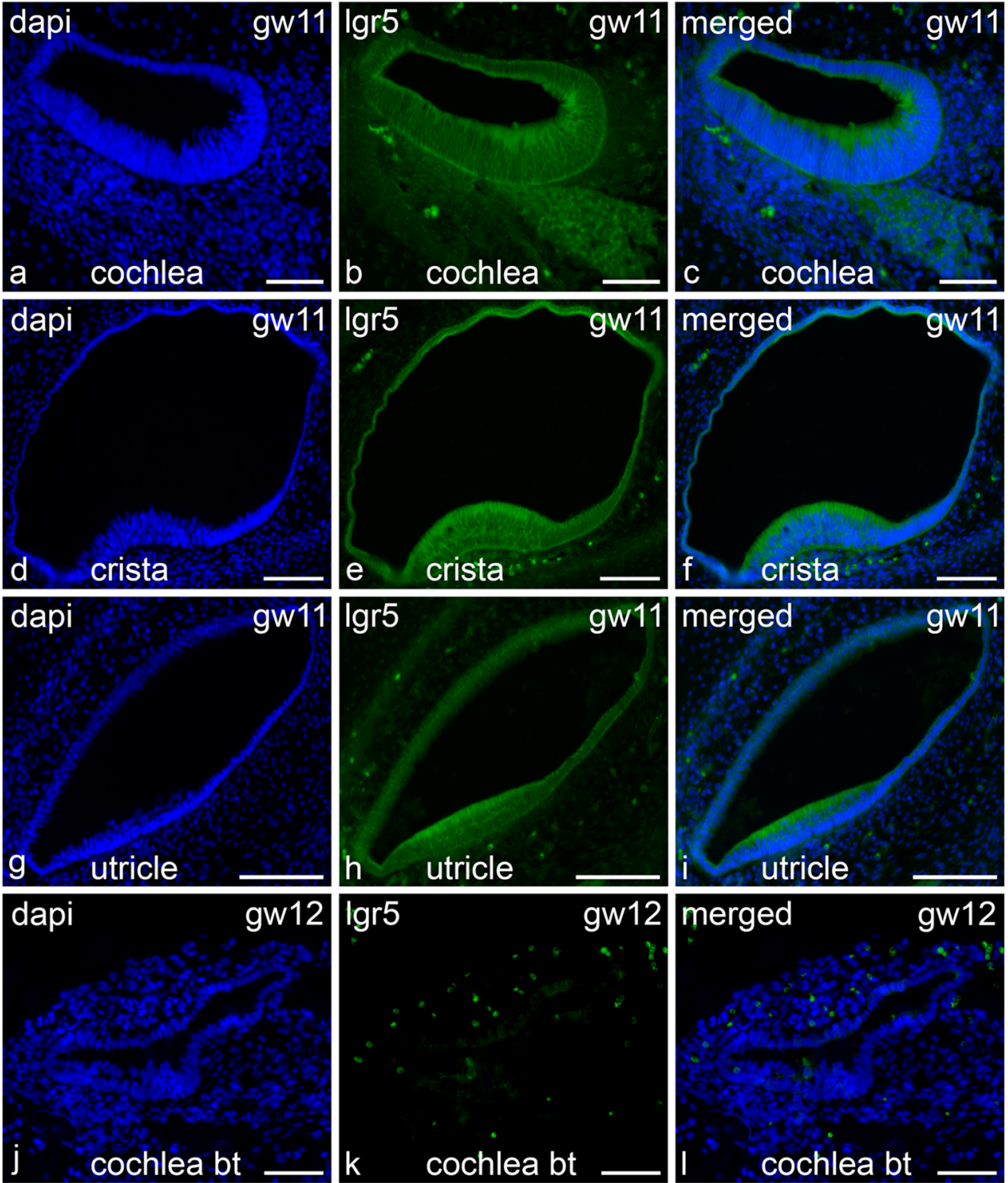

gw12
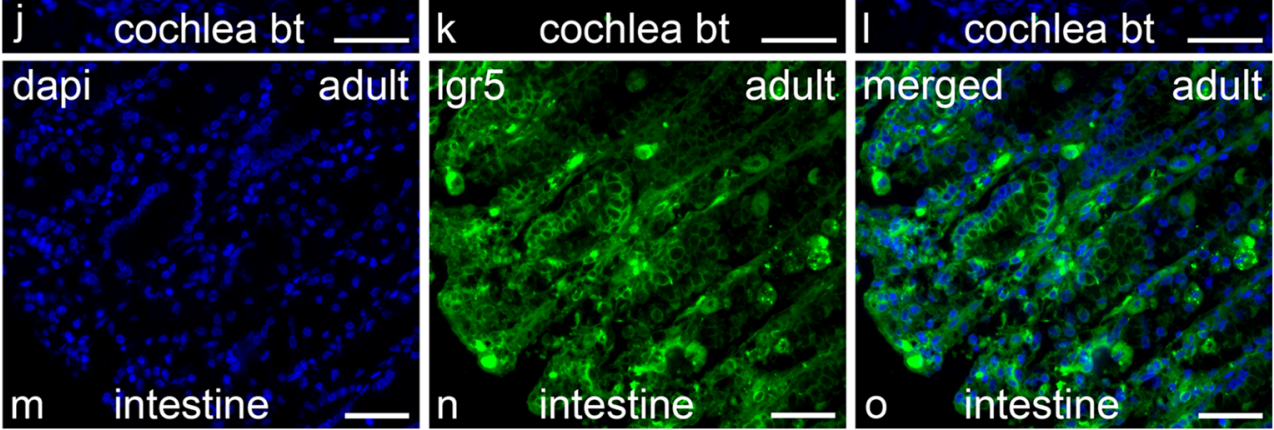

distinct in the prosensory domain at GW12 (Johnson Chacko et al. 2017; Locher et al. 2013; Pechriggl et al. 2015). At GW14, the development of the organ of Corti has not yet reached the apex of the cochlea (Fig. 7a). At GW16, the OHCs in the cochlear apex have matured (Fig. 7b). At this time, electron microscopy shows nerve fibers at the base of the IHCs and the cuticular plate and stereocilia are present in the apex of the cochlea (Fig. 7c).

\section{Discussion}

Damage or loss of IHCs and spiral ganglion cells severely affects hearing and is generally irreversible in mammals. Injury to the adult organ of Corti- the hearing organcauses hearing loss and deafness in humans resulting in lowered quality of life. Identification of critical transcription factors and their associated signaling pathways during inner 


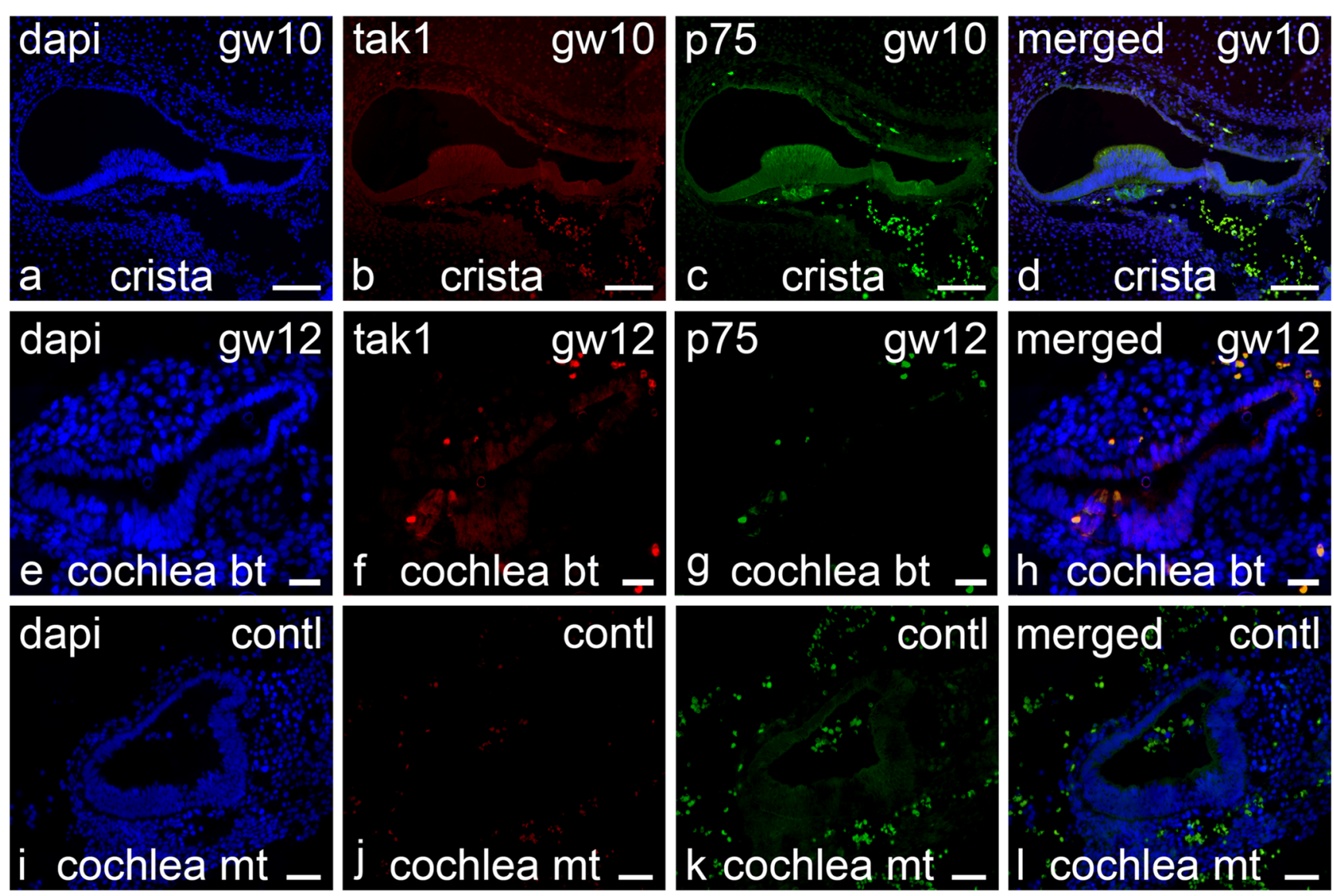

Fig. 2 Immune-stained sections of the developing inner ear during the gestational weeks 10 to 12 . a, e, i Cell nuclei immune stained with DAPI. b-d Immune staining for the TAK1 antibody is absent at this stage; p75 neurotrophic receptor is present at this stage in the vestibular hair cells and nerve fibers of the cristae ampullaris. $\mathbf{f}-\mathbf{h}$ TAK1 first presents in the

ear development could lead to novel strategies to revitalize hair cell receptors in the adult human organ of Corti.

Expression of LGR5, a known Wnt signal enhancer (de Lau et al. 2014), was found to increase from GW8 to 12 in all the fetal inner ear specimens examined. The data seem to parallel previous observations in the fetal cochlea (Roccio et al. 2018) suggesting the presence of a heterogeneous

inner hair cells of the developing organ of Corti at GW12 whereas p75 presents in both inner and outer hair cells at this stage. $\mathbf{j}$-I Control sections lack positive immune staining with the exception of the auto-fluorescence seen in the blood cells. Scale bars: a-d $100 \mu \mathrm{m} ; \mathbf{e}-\mathbf{l} 50 \mu \mathrm{m}$

population of progenitor cells. The LGR5 protein complex was localized in the apical poles of the cochlear sensory epithelia and the SGCs at GW11. At GW12, LGR5 dissipates and limits to cochlear hair cells. Meanwhile, in the vestibulum, the expression was more widespread in the apical poles of the vestibular hair cells lining the cristae ampullaris and the utricle.
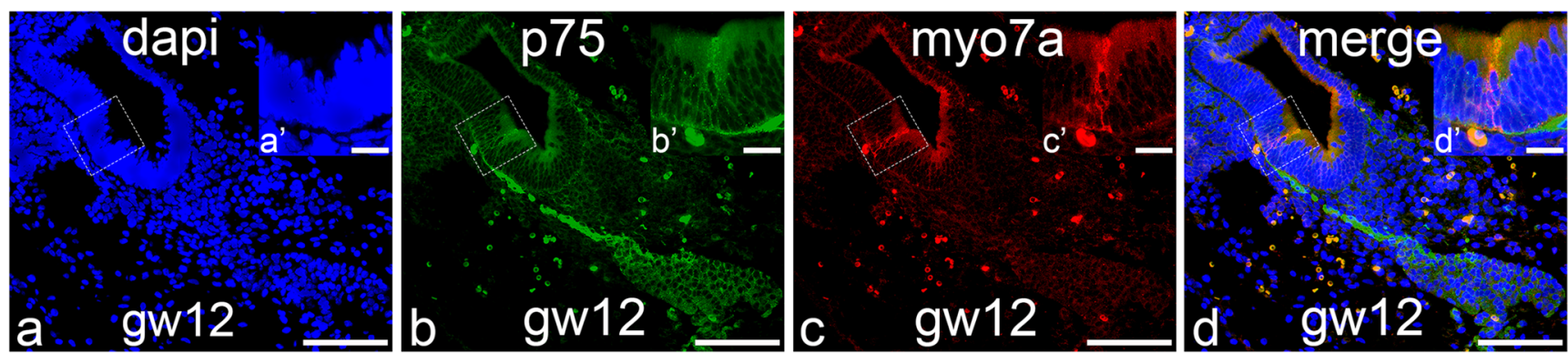

Fig. 3 Immune-stained section of the middle turn of the developing cochlea during the gestational week 12. a Cell nuclei immune stained with DAPI. b p75NTR immune staining presents in the cochlear nerve fibers. The stained fibers penetrate the cochlear sensory epithelia towards the future hair cells. c Myosin VIIA immune staining positive in the

maturing hair cells of the sensory epithelia. d Merged image with myosin VIIa immune reactivity colocalizing with the p75NTR in the maturing hair cells. Insets (a'-d'): higher magnification view of the sensory epithelia. Scale bars: a-d $100 \mu \mathrm{m}$; a-d insets $20 \mu \mathrm{m}$ 
Fig. 4 Immune-stained section of the developing inner ear during the gestational week 9. First evidence for the SOX2 immune staining in the utricle with the supporting cells immune stained. a Cell nuclei immune stained with DAPI. b, c SOX2 immune staining in the vestibular supporting cells. Scale bars: a-c $50 \mu \mathrm{m}$
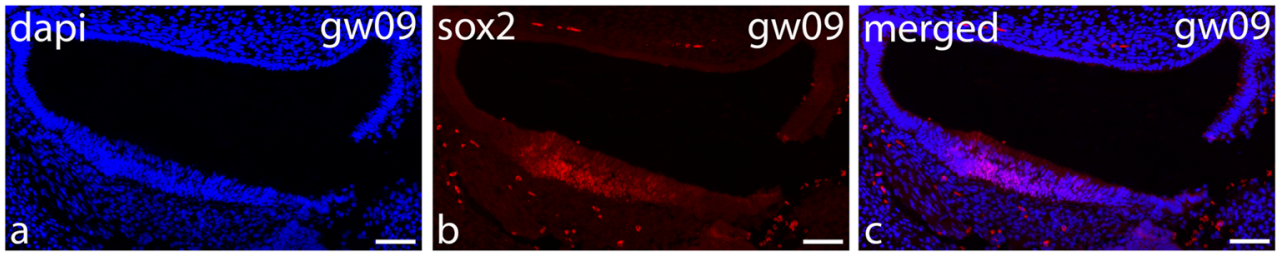

Immunostaining for the transcription factor TAK1 was absent in the vestibular hair cells but present in both the IHCs and OHCs of the fetal cochlea at GW12. The expression colocalized with the p75NTR at GW12 in the cochlear hair
Fig. 5 (a) Overview of the developing inner ear at gestational week 11. GATA3 immune staining is evident in the sensory epithelia of the cochlear epithelium of the apical (at), middle (mt), and basal turns (bt) and the spiral ganglia (spg). The striolar cells in the utricle (U) and the saccule (S) are immune stained by this antibody. (a') Regions corresponding to the greater epithelial ridge (GER), lower epithelial ridge (LER) region, and the Kölliker's organ (KO) in the cochlear sensory epithelia of the basal turn are immune stained. The developing stria vascularis lack staining for this antibody. (a") Higher magnification of the saccule (S) with the supporting cells of the striolar region being immune stained; immune staining for this antibody is absent in the extrastriolar region. (a"') Higher magnification of the utricle (U) with the supporting cells of the striolar region being immune stained; immune staining for this antibody is present also among the transitional cells (TC). Note: GATA3 immune staining extends via the midline of the utricle to the striolar part of the utricle. (b) Myosin VIIa immune staining in the cristae ampullaris at GW9, with the vestibular hair cells immune stained at this stage. (c) In contrast to the vestibulum, the myosin VIIa immune staining in the fetal organ of Corti (OC) appears at GW11 with both the inner and outer hair cells immune stained. Scale bars: (a) $200 \mu \mathrm{m}$; (a', a", a"', b) $50 \mu \mathrm{m}$; (c) $20 \mu \mathrm{m}$
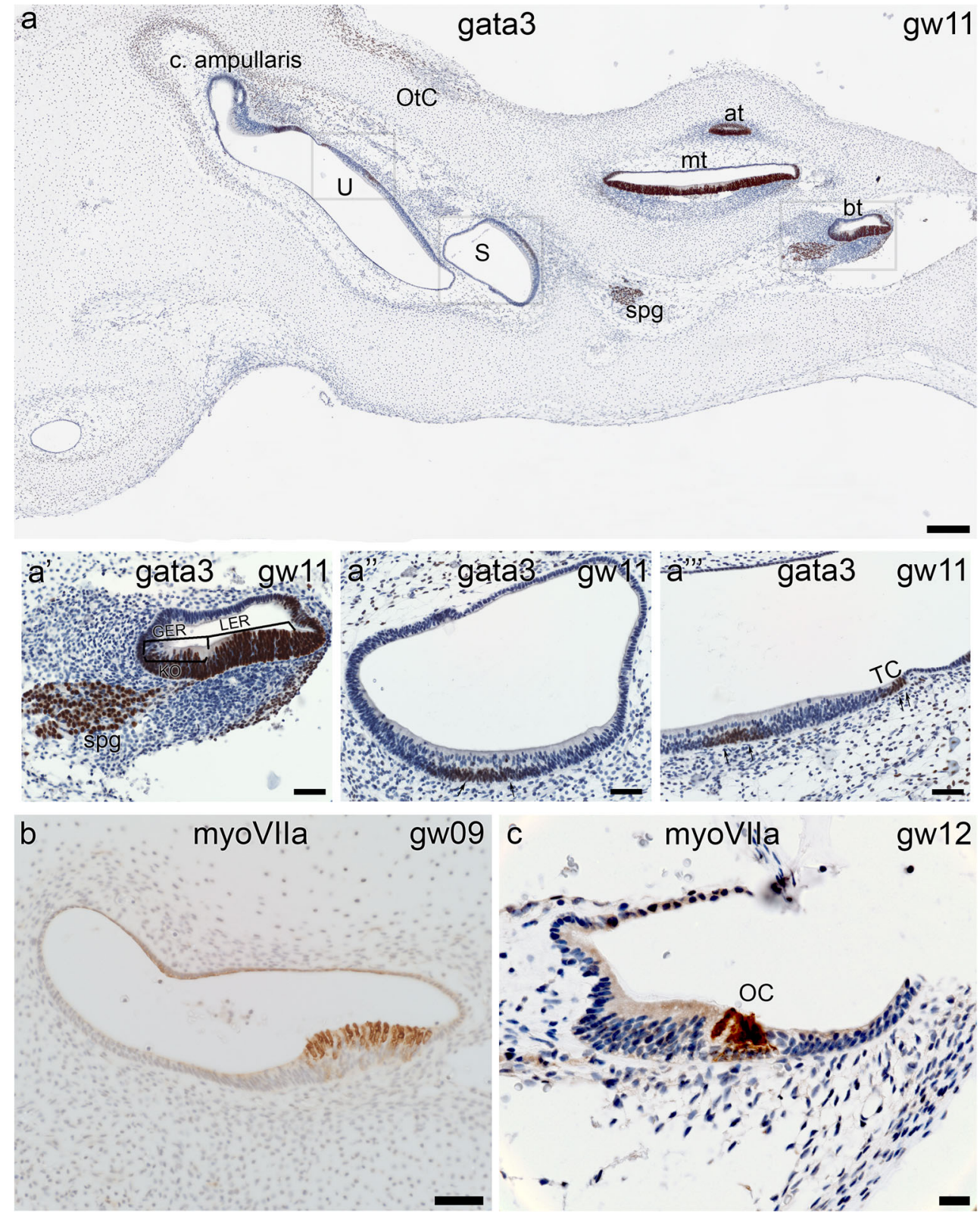

* myoVisa

gw12 
Fig. 6 Transmission electron micrograph of the developing inner ear at gestational weeks 9-11. a Undifferentiated epithelial cells lining the cochlear duct apparent at GW9. b The future organ of Corti appears differentiated and distinct from the prosensory region where cellular differentiation is just starting at GW11. c The nerve fibers (arrowheads) are just starting to enter the cochlear sensory epithelial lining at this stage. BC blood cells, future OC future organ of Corti, Nv nerve. Scale bars: a $25 \mu \mathrm{m} ; \mathbf{b} 10 \mu \mathrm{m} ; \mathbf{c} 2 \mu \mathrm{m}$

cells. The pillar cells are positive in the murine cochlea for p75NTR, and we had previously reported positive immune staining for this marker in the inner pillars at GW12 (Johnson Chacko et al. 2017). Expression for p75NTR in the pillar cells are not apparent in this section plane at the basal turn of the cochlea. Using a myosin VIIa immune staining, we were able to clearly demonstrate expression for p75NTR to colocalize with hair cells expressing myosin VIIa in the middle turn of the developing cochlea at GW12.

In contrast to the SOX2 expression observed previously in the prosensory domain of the cochlea previously (Locher et al. 2013), immune staining for this transcription factor occurred primarily in the vestibular supporting cells of the fetal utricle. This suggests a regulatory role for SOX2 in guiding vestibular supporting cell differentiation. SOX2 also plays a role in maintaining stem cell pluripotency in concert with other transcription factors like Nanog (Boyer et al. 2005; Kempfle et al. 2016), whose expression we could not verify in the developing fetal inner ear. The Nanog antibody positively stained tumor cells from head and neck carcinomas acting as positive controls. This absence of Nanog expression may suggest that the inner ear cells are multipotent rather than pluripotent by this stage of development.

The localization of the GATA3 transcription factor in the striolar region of the utricle and the saccule indicates an early maturation of the vestibular hair cells. This transcription factor is the only known marker for the striolar reversal zone (Alvarado et al. 2009). Vestibular hair cells undergo an $180^{\circ}$ shift in orientation in this zone (Flock 1964) with type I hair cells lining the striolar zone and type II hair cells the extra-striolar regions (Lysakowski and Goldberg 1997). Calyx-only innervated afferents exist in the striolar regions (Desai et al. 2005a; Desai et al. 2005b). Early onset of this switch in hair cell phenotype would suggest the beginning of vestibular functionality at GW18 as evidenced by the presence of mature vestibular calyxes (Lim et al. 2014). The earliest time point for fully adult-like vestibular hair cells immune stained for myosin VIIa was in the cristae ampullaris at GW9. We previously observed positive immune staining for glutamine synthetase (Johnson Chacko et al. 2016), a metabolic regulator of glutamate in the transitional cells of the vestibular end organs. Lineage-specific expression of glutamine synthetase in luminal cells of breast epithelia enables cellular
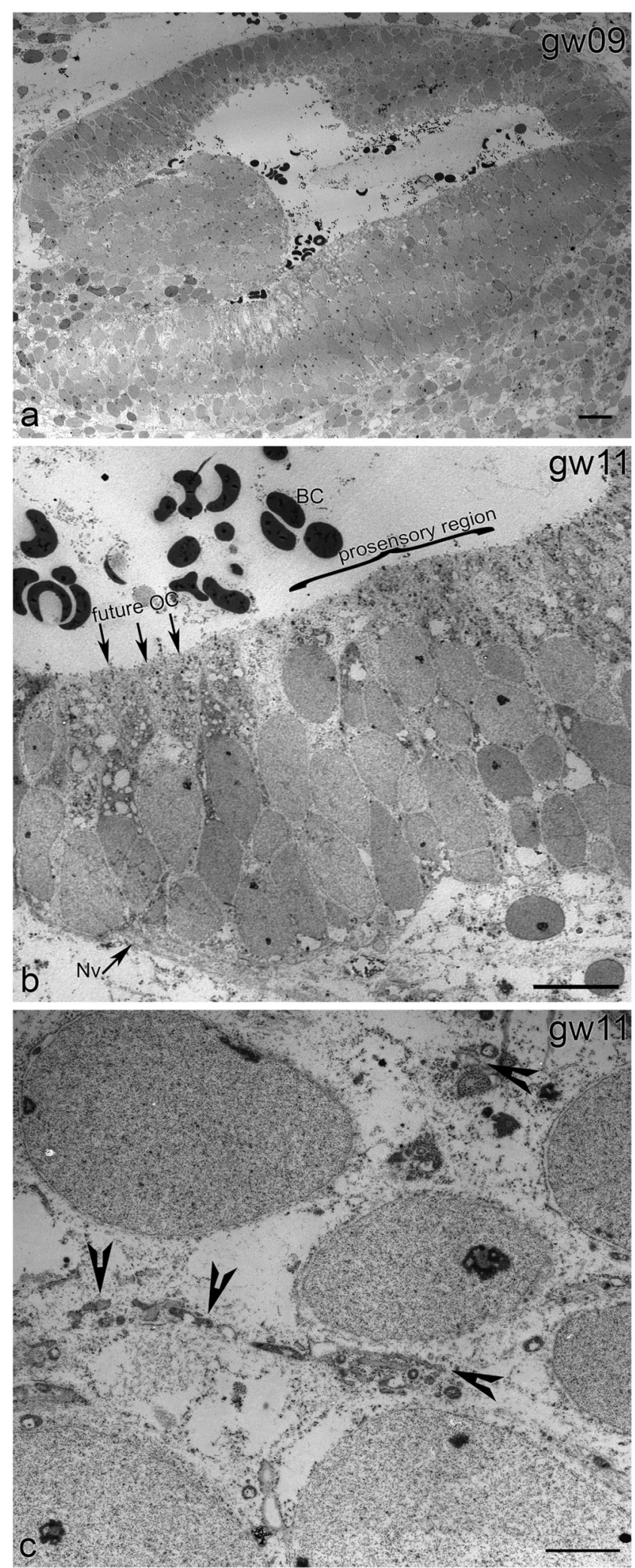

survival (Kung et al. 2011). Expression of GATA3 in the transitional cells of the vestibular end organs could have a similar effect. 


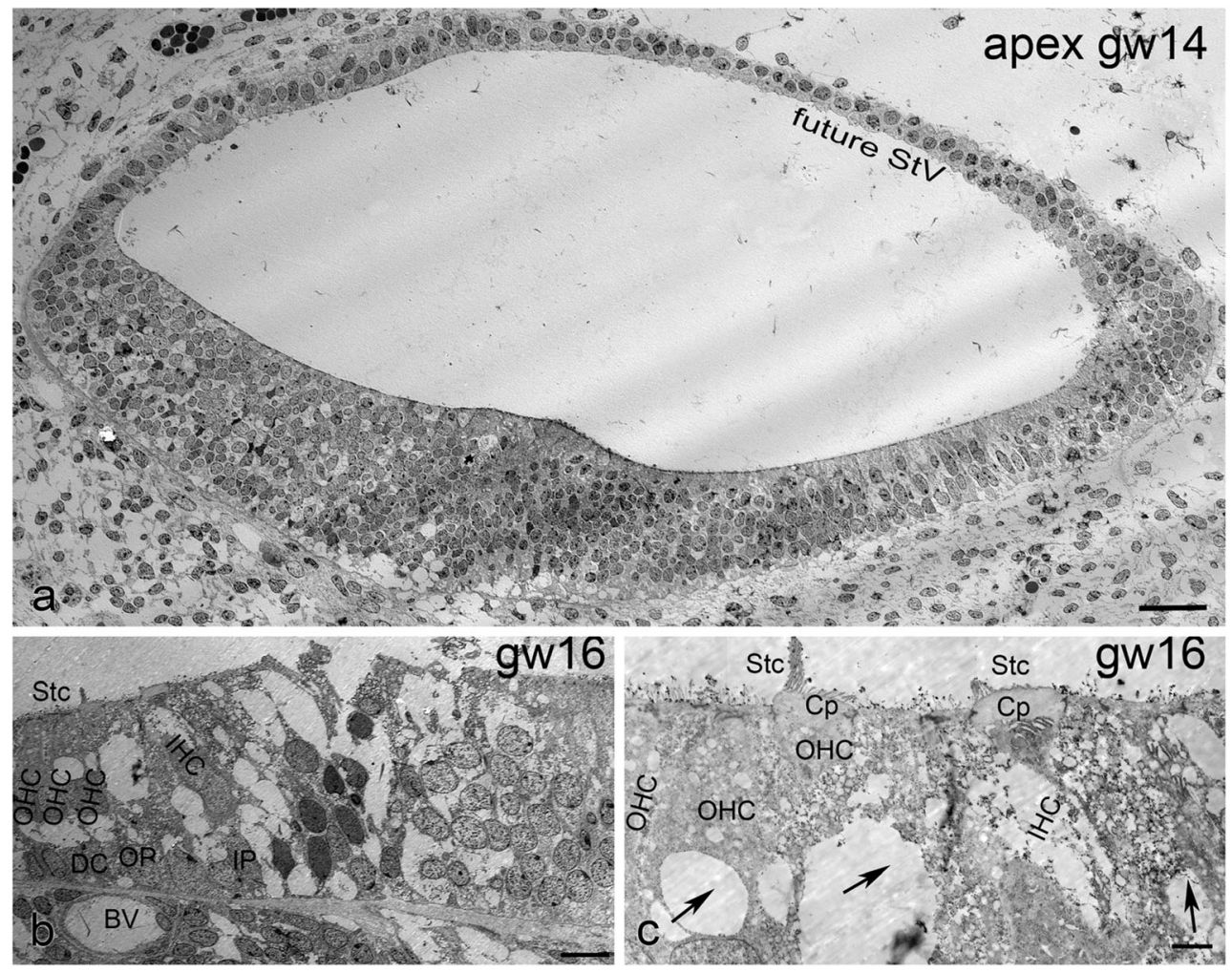

Fig. 7 Transmission electron micrograph of the developing inner ear at gestational weeks 14-16. a In the cochlear apex, the cochlear duct at gestational week 14, the prosensory region of the organ of Corti is distinct while the region corresponding to the cochlear hair cells is still undifferentiated. In the stria vascularis, the basal cells are distinct and appear bilayered. b By gestation week 16, one row of inner hair cells and three rows of outer hair cells are evident with the tunnel of Corti starting to form. One blood vessel (BV) is evident underneath the inner hair cell and underlying the basilar membrane. c Higher magnification imaging of the region of the inner hair cells at gestational week 16 reveals the newly formed cuticular plate $(\mathrm{Cp})$ with the stereocilia (Stc) lining it evident at this stage. Arrows point towards the vacuoles, which will be filled with the nerve fibers. Scale bars: a $25 \mu \mathrm{m} ; \mathbf{b} 10 \mu \mathrm{m}$; c $2 \mu \mathrm{m}$
The expression of GATA 3 observed in the cochlear sensory epithelia at GW11 indicates a turnover of epithelial cells occurring in the cochlea prior to its cochlear maturation. In the murine inner ear, absence of GATA3 results in a cochlear duct with undifferentiated cochlear hair cells and SG in the modiolus. Expression of GATA3 is necessary for neurosensory development (Duncan and Fritzsch 2013) and preventing initiation of apoptotic pathways (Tsarovina et al. 2010) at a time point with most critical differentiation of cochlear sensory epithelia and ganglia occurs. GATA3 expression could signal auditory specification via multiple gene expression cascades, one of which could be the associated transcriptional factor MAFB. We observed MAFB expression in the fetal cochlear (Pechriggl et al. 2015) and vestibular ganglia (Johnson Chacko et al. 2016) between the gestational weeks 8 and 12. MAFB was previously reported to be part of a GATA3-MAFB transcriptional network directing postsynaptic differentiation in auditory synapses (Yu et al. 2013), an indication of its role in SG terminal differentiation. The timely expression of the transcription factors GATA3 and SOX2 observed here with MAFB (Johnson Chacko et al. 2016; Pechriggl et al. 2015) suggests the existence of a cochlear prosensory gene-signaling cascade. This signaling cascade could be similar to the cooperative interaction of SOX2, SIX1, and EYA1 proteins in guiding ATOH1mediated hair cell specification (Ahmed et al. 2012).

There is a large number of undifferentiated epithelial cells at GW9 in the cochlear duct at the electron microscopic level. In addition, there is no differentiation of hair cells and typical supporting cells. In a previous investigation using myosin VIIA marker, the first sign of cochlear hair cell differentiation was identified at GW10 (Johnson Chacko et al. 2017), which was completed at GW12 in the cochlear basal turn. At GW11 and using transmission electron microscopy (TEM), the future $\mathrm{OHCs}$ were visible while the prosensory region is still undergoing substantial cellular differentiation. TEM showed migrating nerve fibers at the base of the OHCs. In a previous study from our lab, the neurotransmitter glutamate immune staining occurred as dots in the sensory neural epithelia in this region at GW11 (Pechriggl et al. 2015) suggesting that these are afferent fibers. Expression of the efferent neurotransmitter GABA was absent in the same region at this stage.

Hair cell differentiation from GW10 onwards (Johnson Chacko et al. 2017) is not complete at the apex of the cochlea 
at GW14. Electron microscopically, Kölliker's organ presents as a dense mass of undifferentiated cells at GW14 while the prosensory region demonstrates signs of cellular patterning. The future stria vascularis is bilayered with future intermediate cells invading. These intermediate cells are of neural crest origin (Schrott and Spoendlin 1987). We can clearly distinguish the OHC, IHCs, and the stereocilia first at GW16 in the apex. The stereocilia and the cuticular plate are also evident with nerve fibers penetrating until the base of the inner pillar cells. This completes hair cell differentiation in the cochlear apex. The late differentiation is consistent with both mouse (Kopecky et al. 2013) and human data (between GW9 and 12) (Roccio et al. 2018) that show a counter gradient of cell cycle exit (apex to base) and differentiation (base to apex). Using higher vertebrate model systems with fetal hearing onset can serve to correlate murine hair cell development and differentiation pattern with human inner ear development (Wang et al. 2018).

We exploited the combined approach using light fluorescence and electron microscopy to study the development of the human fetal inner ear. Information gained from these human investigations may help further characterize significant time-dependent steps in the formation of this complex cyto-architecture. It may also give valuable insights into developmental disorders and pathogenesis of malformations of the inner ear. These fascinating cellular events including apoptosis and shaping involve enzymatic degradation in the maturing Kölliker's organ (Pechriggl et al. 2015) just prior to its remodeling into the organ of Corti.

Acknowledgments We gratefully acknowledge the excellent support of Dr. H. Wolf and his team in the conservation of the human samples. In addition, we would like to thank Annabella Knab for her admirable work with the tissue sectioning. We thank the Institute of Zoology and Center of Molecular Bioscience Innsbruck, University of Innsbruck, Technikerstrasse 25, A-6020 Innsbruck, Austria, for providing infrastructure for TEM examination.

Funding Information Open access funding provided by Austrian Science Fund (FWF). This research has been financially supported by the funding programs of the "Autonome Provinz Bozen Südtirol" [CUP number: B26J16000420003] and the "K-regio project eVITA" (electrical Vestibular Implant Tirol Austria) sponsored by EFRE (Dieses Projekt wird aus Mitteln des Europäischen Fonds für regionale Entwicklung kofinanziert, www.efre.gv.at). The Austrian Science Fund FWF Austria, project I 4147-B (Modelling electrical stimulation of the human cochlear nerve), also supported this research. This study was also supported by research of the European Community Research: Human stem cell applications for the treatment of hearing loss (Grant Agreement No. 603029; project acronym: OTOSTEM (HRA)).

\section{Compliance with ethical standards}

Conflict of interest The authors declare that there is no conflict of interest.
Ethical approval Specimens aged between GW8 and GW12 used in this study were obtained immediately after legally permitted abortion procedures according to the Austrian law ( $\$ 97 \mathrm{StGB}$ of the Austrian Criminal Law as promulgated on 13th November 1998, Federal Law Gazette I). Cadaver donations to the Division of Clinical and Functional Anatomy of the Medical University of Innsbruck for scientific and educational purposes occur only with the informed consent of the donor collected before death. The donors/parents declare during their lifetime that their dead bodies are to be consigned to the anatomical institute for research purposes and the education and advanced training of medical doctors. All embryological body and tissue donations (between the gestational ages 8 and 12) are also released to the anatomical institute by the legally entitled person (mother) accompanied by written consent. In Austria, research projects using these anatomical tissue samples do not need any further approval by an ethics committee of the University.

The other samples (GW14 and 16) are from the filing system of the Institute of Pathology of the Medical University of Innsbruck. For the usage of these specimens, an ethical commission vote was obtained before commencing this research. This study was approved by the Ethical Commission of the Medical University of Innsbruck (Studienzahl UN2817 Sitzungsnummer 249/4.5; original title of the research proposal: Immunhistochemische Untersuchung von Felsenbeinen mit dazugehöriger Hörbahn). In Austria, there is no requirement for a consent of the parents or relatives for a clinical autopsy performed in a medical institution $\$ 25 \mathrm{KAKuG}$ Leichenöffnung (Obduktion) (Krankenanstalten- und Kuranstaltengesetz). [(1) The corpses of deceased patients in public hospitals are to be autopsied if the autopsy has been ordered by sanitary or criminal prosecutors, or if it is necessary for public or scientific interests, in the situation of diagnostic uncertainty of the case or after surgical intervention.

(2) If none of the cases mentioned in paragraph 1 is present and the deceased has not consented to an autopsy during his lifetime, an autopsy may only be carried out with the consent of the next of kin.

(3) A copy of the medical history shall be recorded for each autopsy and kept in accordance with $\S 10,1 \mathrm{Z} .3$.

In the past, $\$ 25 \mathrm{KAKuG}$ was labeled as $\$ 25 \mathrm{KAG}$ (Krankenanstaltengesetz)].

However, in specific cases, a limited autopsy or a postmortem biopsy of one or two organs with closed body is performed in lieu of a full autopsy. In Austria, this autopsy procedure allows institutions to keep the autopsy rate to a higher level than the level of other Western countries permitting high standards of quality assurance and quality controls in most of the healthcare institutions (Leitner 2009).

Open Access This article is licensed under a Creative Commons Attribution 4.0 International License, which permits use, sharing, adaptation, distribution and reproduction in any medium or format, as long as you give appropriate credit to the original author(s) and the source, provide a link to the Creative Commons licence, and indicate if changes were made. The images or other third party material in this article are included in the article's Creative Commons licence, unless indicated otherwise in a credit line to the material. If material is not included in the article's Creative Commons licence and your intended use is not permitted by statutory regulation or exceeds the permitted use, you will need to obtain permission directly from the copyright holder. To view a copy of this licence, visit http://creativecommons.org/licenses/by/4.0/.

\section{References}

Agrawal Y, Carey JP, Della Santina CC, Schubert MC, Minor LB (2009) Disorders of balance and vestibular function in US adults: data from the National Health and Nutrition Examination Survey, 2001-2004. Arch Intern Med 169:938-944 
Ahmed M, Wong EY, Sun J, Xu J, Wang F, Xu PX (2012) Eya1-Six1 interaction is sufficient to induce hair cell fate in the cochlea by activating Atoh1 expression in cooperation with Sox2. Dev Cell 22:377-390

Alvarado DM, Veile R, Speck J, Warchol M, Lovett M (2009) Downstream targets of GATA3 in the vestibular sensory organs of the inner ear. Dev Dyn 238:3093-3102

Beat MR, Bolt S, Brenner E, Bueno-López JL, Circulescu ARM, Davies DC, De Caro R, Gerrits PO, McHanwell S, Pais D, Paulsen F, Plaisant O, Sendemir E, Stabile I, Moxham BJ (2012) The legal and ethical framework governing Body Donation in Europe - 1st update on current practice. Eur J Anat 16:1-2

BowlMR, Dawson SJ (2018) Age-related hearing loss. Cold Spring Harb Perspect Med

Boyer LA, Lee TI, Cole MF, Johnstone SE, Levine SS, Zucker JP, Guenther MG, Kumar RM, Murray HL, Jenner RG, Gifford DK, Melton DA, Jaenisch R, Young RA (2005) Core transcriptional regulatory circuitry in human embryonic stem cells. Cell 122:947956

Bramhall NF, Shi F, Arnold K, Hochedlinger K, Edge AS (2014) Lgr5positive supporting cells generate new hair cells in the postnatal cochlea. Stem Cell Reports 2:311-322

Burns JC, Stone JS (2017) Development and regeneration of vestibular hair cells in mammals. Semin Cell Dev Biol 65:96-105

Chai R, Kuo B, Wang T, Liaw EJ, Xia A, Jan TA, Liu Z, Taketo MM, Oghalai JS, Nusse R, Zuo J, Cheng AG (2012) Wnt signaling induces proliferation of sensory precursors in the postnatal mouse cochlea. Proc Natl Acad Sci U S A 109:8167-8172

Dabdoub A, Puligilla C, Jones JM, Fritzsch B, Cheah KS, Pevny LH, Kelley MW (2008) Sox2 signaling in prosensory domain specification and subsequent hair cell differentiation in the developing cochlea. Proc Natl Acad Sci U S A 105:18396-18401

de Lau W, Peng WC, Gros P, Clevers H (2014) The R-spondin/Lgr5/ Rnf43 module: regulator of Wnt signal strength. Genes Dev 28: 305-316

Desai SS, Ali H, Lysakowski A (2005a) Comparative morphology of rodent vestibular periphery. II. Cristae ampullares. J Neurophysiol 93:267-280

Desai SS, Zeh C, Lysakowski A (2005b) Comparative morphology of rodent vestibular periphery. I. Saccular and utricular maculae. J Neurophysiol 93:251-266

Dudas J, Dietl W, Romani A, Reinold S, Glueckert R, Schrott-Fischer A, Dejaco D, Johnson Chacko L, Tuertscher R, Schartinger VH, Riechelmann H (2018) Nerve growth factor (ngf)-receptor survival axis in head and neck squamous cell carcinoma. Int J Mol Sci 19:

Duncan JS, Fritzsch B (2013) Continued expression of GATA3 is necessary for cochlear neurosensory development. PLoS One 8:e62046

Dvorakova M, Jahan I, Macova I, Chumak T, Bohuslavova R, Syka J, Fritzsch B, Pavlinkova G (2016) Incomplete and delayed Sox2 deletion defines residual ear neurosensory development and maintenance. Sci Rep 6:38253

Economou A, Datta P, Georgiadis V, Cadot S, Frenz D, Maconochie M (2013) Gata3 directly regulates early inner ear expression of Fgf10. Dev Biol 374:210-222

Flock A (1964) Structure of the macula utriculi with special reference to directional interplay of sensory responses as revealed by morphological polarization. J Cell Biol 22:413-431

Fritzsch B, Elliott KL, Pavlinkova G, Duncan JS, Hansen MR, Kersigo JM (2019) Neuronal migration generates new populations of neurons that develop unique connections, physiological properties and pathologies. Front Cell Dev Biol 7:59

Hagstrom SA, Pauer GJ, Reid J, Simpson E, Crowe S, Maumenee IH, Traboulsi EI (2005) SOX2 mutation causes anophthalmia, hearing loss, and brain anomalies. Am J Med Genet A 138A:95-98

Higgins JP, Kaygusuz G, Wang L, Montgomery K, Mason V, Zhu SX, Marinelli RJ, Presti JC Jr, van de Rijn M, Brooks JD (2007)
Placental S100 (S100P) and GATA3: markers for transitional epithelium and urothelial carcinoma discovered by complementary DNA microarray. Am J Surg Pathol 31:673-680

Johnson Chacko L, Pechriggl EJ, Fritsch H, Rask-Andersen H, Blumer MJ, Schrott-Fischer A, Glueckert R (2016) Neurosensory differentiation and innervation patterning in the human fetal vestibular end organs between the gestational weeks 8-12. Front Neuroanat 10:111

Johnson Chacko L, Blumer MJF, Pechriggl E, Rask-Andersen H, Dietl W, Haim A, Fritsch H, Glueckert R, Dudas J, Schrott-Fischer A (2017) Role of BDNF and neurotrophic receptors in human inner ear development. Cell Tissue Res 370:347-363

Karis A, Pata I, van Doorninck JH, Grosveld F, de Zeeuw CI, de Caprona D, Fritzsch B (2001) Transcription factor GATA-3 alters pathway selection of olivocochlear neurons and affects morphogenesis of the ear. J Comp Neurol 429:615-630

Kempfle JS, Turban JL, Edge AS (2016) Sox2 in the differentiation of cochlear progenitor cells. Sci Rep 6:23293

Kiernan AE, Pelling AL, Leung KK, Tang AS, Bell DM, Tease C, LovellBadge R, Steel KP, Cheah KS (2005) Sox 2 is required for sensory organ development in the mammalian inner ear. Nature 434:1031-1035

Kim MS, Cho HI, Yoon HJ, Ahn YH, Park EJ, Jin YH, Jang YK (2018) JIB-04, A small molecule histone demethylase inhibitor, selectively targets colorectal cancer stem cells by inhibiting the Wnt/betacatenin signaling pathway. Sci Rep 8:6611

Kopecky BJ, Jahan I, Fritzsch B (2013) Correct timing of proliferation and differentiation is necessary for normal inner ear development and auditory hair cell viability. Dev Dyn 242:132-147

Kung HN, Marks JR, Chi JT (2011) Glutamine synthetase is a genetic determinant of cell type-specific glutamine independence in breast epithelia. PLoS Genet 7:e1002229

Leitner B (2009) Todesursachenstatistik und Obduktionen. österreichische ärztezeitung:9

Lim R, Drury HR, Camp AJ, Tadros MA, Callister RJ, Brichta AM (2014) Preliminary characterization of voltage-activated whole-cell currents in developing human vestibular hair cells and calyx afferent terminals. J Assoc Res Otolaryngol 15:755-766

Lindsay SL, Johnstone SA, McGrath MA, Mallinson D, Barnett SC (2016) Comparative miRNA-based fingerprinting reveals biological differences in human olfactory mucosa- and bone-marrow-derived mesenchymal stromal cells. Stem Cell Reports 6:729-742

Liu W, Edin F, Atturo F, Rieger G, Lowenheim H, Senn P, Blumer M, Schrott-Fischer A, Rask-Andersen H, Glueckert R (2015) The preand post-somatic segments of the human type I spiral ganglion neurons - structural and functional considerations related to cochlear implantation. Neuroscience 284:470-482

Locher H, Frijns JH, van Iperen L, de Groot JC, Huisman MA, Chuva de Sousa Lopes SM (2013) Neurosensory development and cell fate determination in the human cochlea. Neural Dev 8:20

Lysakowski A, Goldberg JM (1997) A regional ultrastructural analysis of the cellular and synaptic architecture in the chinchilla cristae ampullares. J Comp Neurol 389:419-443

Mak AC, Szeto IY, Fritzsch B, Cheah KS (2009) Differential and overlapping expression pattern of SOX2 and SOX9 in inner ear development. Gene Expr Patterns 9:444-453

Mann ZF, Thiede BR, Chang W, Shin JB, May-Simera HL, Lovett M, Corwin JT, Kelley MW (2014) A gradient of Bmp7 specifies the tonotopic axis in the developing inner ear. Nat Commun 5:3839

Matei V, Pauley S, Kaing S, Rowitch D, Beisel KW, Morris K, Feng F, Jones K, Lee J, Fritzsch B (2005) Smaller inner ear sensory epithelia in Neurog 1 null mice are related to earlier hair cell cycle exit. Dev Dyn 234:633-650

McLean WJ, McLean DT, Eatock RA, Edge AS (2016) Distinct capacity for differentiation to inner ear cell types by progenitor cells of the cochlea and vestibular organs. Development 143:4381-4393

McLean WJ, Yin X, Lu L, Lenz DR, McLean D, Langer R, Karp JM, Edge ASB (2017) Clonal expansion of Lgr5-positive cells from 
mammalian cochlea and high-purity generation of sensory hair cells. Cell Rep 18:1917-1929

McHanwell S. BE, Chirculescu ARM, Drukker J, van Mameren H, Mayyotti G, Pais D, Paulsen F, Plaisant O, Caillaud MM, Laforet E, Riedere BM, Sanudo JR, Bueno-Lopey JL, Donate Oliver F, Sprumont P, Teofilovski-Parapid G, Moxham BJ (2008) The legal and ethical framework governing Body Donation in Europe - A review of current practice and recommendations for good practice. Eur J Anat 12:1-24

Moriguchi T, Hoshino T, Rao A, Yu L, Takai J, Uemura S, Ise K, Nakamura Y, Lim KC, Shimizu R, Yamamoto M, Engel JD (2018) A Gata3 3' distal otic vesicle enhancer directs inner earspecific Gata3 expression. Mol Cell Biol 38

Nishimura K, Noda T, Dabdoub A (2017) Dynamic expression of Sox2, Gata3, and Prox1 during primary auditory neuron development in the mammalian cochlea. PLoS One 12:e0170568

Okita K, Ichisaka T, Yamanaka S (2007) Generation of germlinecompetent induced pluripotent stem cells. Nature 448:313-317

Parker MA, Jiang K, Kempfle JS, Mizutari K, Simmons CL, Bieber R, Adams J, Edge AS (2011) TAK1 expression in the cochlea: a specific marker for adult supporting cells. J Assoc Res Otolaryngol 12: $471-483$

Pauley S, Wright TJ, Pirvola U, Ornitz D, Beisel K, Fritzsch B (2003) Expression and function of FGF10 in mammalian inner ear development. Dev Dyn 227:203-215

Pechriggl EJ, Bitsche M, Glueckert R, Rask-Andersen H, Blumer MJ, Schrott-Fischer A, Fritsch H (2015) Development of the innervation of the human inner ear. Dev Neurobiol 75:683-702

Puligilla C, Dabdoub A, Brenowitz SD, Kelley MW (2010) Sox2 induces neuronal formation in the developing mammalian cochlea. $\mathrm{J}$ Neurosci 30:714-722

Rauch SD, Velazquez-Villasenor L, Dimitri PS, Merchant SN (2001) Decreasing hair cell counts in aging humans. Ann N Y Acad Sci 942:220-227
Roccio M, Perny M, Ealy M, Widmer HR, Heller S, Senn P (2018) Molecular characterization and prospective isolation of human fetal cochlear hair cell progenitors. Nat Commun 9:4027

Schrott A, Spoendlin H (1987) Pigment anomaly-associated inner ear deafness. Acta Otolaryngol 103:451-457

Smeti I, Assou S, Savary E, Masmoudi S, Zine A (2012) Transcriptomic analysis of the developing and adult mouse cochlear sensory epithelia. PLoS One 7:e42987

Soni LE, Warren CM, Bucci C, Orten DJ, Hasson T (2005) The unconventional myosin-VIIa associates with lysosomes. Cell Motil Cytoskeleton 62:13-26

Tsarovina K, Reiff T, Stubbusch J, Kurek D, Grosveld FG, Parlato R, Schutz G, Rohrer H (2010) The Gata3 transcription factor is required for the survival of embryonic and adult sympathetic neurons. J Neurosci 30:10833-10843

Van Esch H, Groenen P, Nesbit MA, Schuffenhauer S, Lichtner P, Vanderlinden G, Harding B, Beetz R, Bilous RW, Holdaway I, Shaw NJ, Fryns JP, Van de Ven W, Thakker RV, Devriendt K (2000) GATA3 haplo-insufficiency causes human HDR syndrome. Nature 406:419-422

Wang L, Kempton JB, Brigande JV (2018) Gene therapy in mouse models of deafness and balance dysfunction. Front Mol Neurosci $11: 300$

Yu WM, Appler JM, Kim YH, Nishitani AM, Holt JR, Goodrich LV (2013) A Gata3-Mafb transcriptional network directs post-synaptic differentiation in synapses specialized for hearing. Elife 2:e01341

Zhang Y, Guo L, Lu X, Cheng C, Sun S, Li W, Zhao L, Lai C, Zhang S, Yu C, Tang M, Chen Y, Chai R, Li H (2018) Characterization of Lgr6+ cells as an enriched population of hair cell progenitors compared to Lgr5+ cells for hair cell generation in the neonatal mouse cochlea. Front Mol Neurosci 11:147

Publisher's note Springer Nature remains neutral with regard to jurisdictional claims in published maps and institutional affiliations. 